\title{
Enhanced insulin secretion and improved glucose tolerance in mice with homozygous inactivation of the $\mathrm{Na}^{+} \mathrm{K}^{+} 2 \mathrm{Cl}^{-}$co-transporter 1
}

\author{
Saeed Alshahrani and Mauricio Di Fulvio \\ Department of Pharmacology and Toxicology, School of Medicine, Wright State University, 3640 Colonel Glenn Highway, 216 HSB, Dayton, Ohio 45435, USA \\ (Correspondence should be addressed to M Di Fulvio; Email: mauricio.difulvio@wright.edu)
}

\begin{abstract}
The intracellular chloride concentration $\left(\left[\mathrm{Cl}^{-}\right]_{\mathrm{i}}\right)$ in $\beta$-cells plays an important role in glucose-stimulated plasma membrane depolarisation and insulin secretion. $\left[\mathrm{Cl}^{-}\right]_{\mathrm{i}}$ is maintained above equilibrium in $\beta$-cells by the action of $\mathrm{Cl}^{-}$ co-transporters of the solute carrier family 12 group A (Slc12a). $\beta$-Cells express Slc12a1 and Slc12a2, which are known as the bumetanide (BTD)-sensitive $\mathrm{Na}^{+}$-dependent $\mathrm{K}^{+} 2 \mathrm{Cl}^{-}$ co-transporters 2 and 1 respectively. We show that mice lacking functional alleles of the Slc12a2 gene exhibit better fasting glycaemia, increased insulin secretion in response to glucose, and improved glucose tolerance when compared with wildtype (WT). This phenomenon correlated with increased
\end{abstract}

sensitivity of $\beta$-cells to glucose in vitro and with increased $\beta$-cell mass. Further, administration of low doses of BTD to mice deficient in Slc12a2 worsened their glucose tolerance, and low concentrations of BTD directly inhibited glucose-stimulated insulin secretion from $\beta$-cells deficient in Slc12a2 but expressing intact $S l c 12 a 1$ genes. Together, our results suggest for the first time that the Slc12a2 gene is not necessary for insulin secretion and that its absence increases $\beta$-cell secretory capacity. Further, impairment of insulin secretion with BTD in vivo and in vitro in islets lacking Slc12a2 genes unmasks a potential new role for Slc12a 1 in $\beta$-cell physiology.

Journal of Endocrinology (2012) 215, 59-70

\section{Introduction}

Type 2 diabetes mellitus (T2DM) is a poly-endocrine and metabolic disorder characterised by chronic hyperglycaemia and relative insulin deficiency. T2DM is consequence of either prevalent impairment of insulin secretion associated with reduced insulin action on peripheral tissues or to a prevalent tissue resistance to the action of insulin associated with deficient insulin secretion (Del Prato et al. 2002). Insulin is secreted in a well-defined fashion. Depending on the stimulus, two phases of insulin secretion are recognised (Caumo \& Luzi 2004). The first phase, which occurs after $5-10 \mathrm{~min}$ of $\beta$-cell exposure to increased glucose, is characterised by the release of insulin stored in intracellular granules located closely to the plasma membrane (Hou et al. 2009). The second phase requires insulin secretion from storage granules and de novo synthesis of the hormone (Wang \& Thurmond 2009). Under normal physiological conditions, this phase is sustained and lasts until normoglycaemia is reached. Impairment of first-phase insulin secretion is an early finding in T2DM, which usually follows chronic tissue resistance to the action of insulin (Caumo \& Luzi 2004, Kashyap \& Defronzo 2007, Guillausseau et al. 2008).

The best-characterised mechanism whereby glucose stimulates insulin secretion is the ATP-sensitive $\mathrm{K}^{+}{ }_{\left(\mathrm{K}_{\mathrm{ATP}}\right)}$ channel-dependent pathway. In this mechanism, glucose is transported into the $\beta$-cell and metabolised. Glycolysis and mitochondrial respiration results in increased ATP/ADP ratios, closure of $\mathrm{K}_{\mathrm{ATP}}$ channels, decreased $\mathrm{K}^{+}$conductance and depolarisation of the $\beta$-cell plasma membrane. This depolarisation gates voltage-dependent $\mathrm{Ca}^{2+}$ channels promoting $\mathrm{Ca}^{2+}$ influx, the trigger for exocytosis of insulin stored in granules (Drews et al. 2010). However, physiological concentrations of glucose can still promote insulin secretion in the absence of functional $\mathrm{K}_{\mathrm{ATP}}$ channels (Best et al. 1992, 2010, Seghers et al. 2000, Best 2002). This additional $\mathrm{K}_{\mathrm{ATP}}$ channel-independent glucose-sensing mechanism is related to volume-activated ion channels and $\mathrm{Cl}^{-}$efflux (Best $e$ t al. 2010). Naturally electrogenic, $\mathrm{Cl}^{-}$efflux from $\beta$-cells is possible because their intracellular chloride concentration $\left(\left[\mathrm{Cl}^{-}\right]_{\mathrm{i}}\right)$ is maintained higher than it would be predicted by the Nernst equation (Eberhardson et al. 2000). Therefore, $\mathrm{Cl}^{-}$is transported inwardly against its electrochemical gradient in $\beta$-cells. This $\mathrm{Cl}^{-}$transport mechanism was identified as the bumetanide (BTD)-sensitive $\mathrm{Na}^{+} \mathrm{K}^{+} 2 \mathrm{Cl}^{-}$ co-transporter 1 (NKCC1; Majid et al. 2001, Best 2005). The relevance of NKCCs in insulin secretion and glucose homeostasis is exemplified by the fact that BTD and furosemide, inhibitors of NKCCs, directly block glucoseinduced insulin secretion in vivo and in vitro (Furman 1981, Sandstrom 1988, Majid et al. 2001, Best 2005). 
NKCCs belong to the family of solute carriers $\operatorname{Slc} 12 a$, which includes $\mathrm{Na}^{+} \mathrm{K}^{+} 2 \mathrm{Cl}^{-}$(Slc12a1 and Slc12a2), $\mathrm{Na}^{+} \mathrm{Cl}^{-}$(NCCs, Slc12a3) and $\mathrm{K}^{+} \mathrm{Cl}^{-}$(KCCs, Slc12a4-7) co-transporters (Di Fulvio \& Alvarez-Leefmans 2009). NKCCs and NCCs are active transport mechanisms that accumulate $\mathrm{Cl}^{-}$in the cell using the energy stored in the $\mathrm{Na}^{+}$chemical gradient, kept in all cells by the $\mathrm{Na}^{+} / \mathrm{K}^{+}{ }_{-}$ ATPase, whereas KCCs mediate active $\mathrm{Cl}^{-}$extrusion using the $\mathrm{K}^{+}$gradient as the source of energy (Adragna et al. 2004). NKCCs are the pharmacological targets of BTD, one of the most commonly prescribed drugs for the treatment of oedematous states associated with congestive heart failure and other conditions (Gamba 2005). With few exceptions, including glucagon-secreting $\boldsymbol{\alpha}$-cells (Majid et al. 2001) and most adult neurons (Wang et al. 2002), the pharmacological, functional and/or molecular presence of NKCC has been established in all mammalian cells examined so far (Hoffmann et al. 2009). Pancreatic $\beta$-cells express NKCC1 at the molecular and functional levels (Lindstrom et al. 1988, Sandstrom 1990, Majid et al. 2001). Moreover, we have recently demonstrated that $\beta$-cells express specific splice variants of NKCC1 and NKCC2 (Alshahrani \& Di Fulvio 2012), adding an extra layer of complexity to the mechanisms involved in the regulation of $\left[\mathrm{Cl}^{-}\right]_{\mathrm{i}}$ in these cells.

Contrary to the well-known physiological role of NKCC2 in kidney tubular function (Simon et al. 1996, Ares et al. 2011), the physiological impact of NKCC2 outside tubular cells is unknown. This is partially due to the fact that expression of NKCC2 has been only recently found in extratubular cells. Indeed, NKCC2 is expressed in specialised neurons of the gastrointestinal tract or interneurons (Gavrikov et al. 2006, Xue et al. 2009, Zhu et al. 2011) and in cells of the gastric, intestinal, endolymphatic sac and olfactory epithelia (Akiyama et al. 2007, 2010, Nickell et al. 2007, Nishimura et al. 2009, Xue et al. 2009, Zhu et al. 2011). In fact, low levels of Slc12a1 mRNAs appear to be widely distributed in human tissues (Di Fulvio \& Alvarez-Leefmans 2009). Nevertheless, the physiological role of extra-renal NKCC2 remains to be determined.

Although it is known that $\left[\mathrm{Cl}^{-}\right]_{\mathrm{i}}$ and NKCCs play an important role in glucose-induced insulin secretion and that inhibition of NKCCs with BTD may have a diabetogenic impact in susceptible individuals (Furman 1981), the direct role of NKCC1 on insulin secretion in vivo has not been addressed. The objective of this study is to determine the impact of this co-transporter on glucose-induced insulin secretion and glucose homeostasis in mice deficient in the Slc12a2 gene. In this report, we demonstrate for the first time that mice deficient in NKCC1 exhibit robust insulin secretion in response to glucose, enhanced glucose tolerance and $\beta$-cell secretory capacity. Further, we discover the presence of a BTD-sensitive mechanism involved in insulin secretion in $\beta$-cells lacking NKCC1, thus unmasking a potential new role for NKCC2 in $\beta$-cell physiology.

\section{Materials and Methods}

Animals

All studies performed in animals have been approved by the Institutional Animal Care and Use Committee of Wright State University, Boonshoft School of Medicine. Mice (Mus musculus) lacking a single functional allele of the Slc12a2 gene, i.e. heterozygous $\mathrm{NKCC} 1$ breeders $\left(\mathrm{NKCC} 1^{\mathrm{HE}}\right.$, genetic background 129/SvJ (Flagella et al. 1999)), were used to generate mice colonies of two different genetic backgrounds: 129/SvJ and C57BL/6J. The latter was created by crossing NKCC1 ${ }^{\mathrm{HE}}$ with $\mathrm{C} 57 \mathrm{BL} / 6 \mathrm{~J}$ mice for approximately ten generations. Unless otherwise indicated, C57BL/6J mice of both sexes and of postnatal ages between 20 and 23 days were used in our experiments. All animals had access to a standard chow diet and water ad libitum and were housed under $12 \mathrm{~h}$ light: $12 \mathrm{~h}$ darkness cycles. Mice were genotyped by PCR using genomic DNA extracted from the tip of the mouse's tail or other tissues post-mortem.

\section{Materials and immunochemicals}

Culture supplements, general chemicals and collagenase were from Sigma. Culture media low and high in glucose (RPMI/DMEM) were from Lonza, Inc. (Basel, Switzerland). Pre-casted SDS-polyacrylamide gels, running buffer, protein molecular weight markers and SuperSignal West Pico Chemiluminescence Kits were form Pierce (Thermo Scientific, Rockford, IL, USA). Mouse monoclonal antibodies against NKCC1 (T4c) and pro-insulin (GS-9A8) were from Developmental Studies Hybridoma Bank (DSHB, University of Iowa). Rabbit polyclonal antibodies directed against the C-terminus of rat NKCC2 were a kind gift of Dr Pablo Ortiz (Henry Ford Hospital, Detroit, MI, USA). The specificity of these antibodies has been recently validated (Alshahrani \& Di Fulvio 2012). Secondary goat FITC-, Cy3- or HRPconjugated antibodies were from Jackson ImmunoResearch Laboratories, Inc. (West Grove, PA, USA). Microscopy materials were from Electron Microscopy Sciences (Hatfield, PA, USA).

\section{Islet isolation}

Mice islets were obtained and cultured following the protocol of Li et al. (2009). Briefly, mice were killed by $\mathrm{CO}_{2}$ asphyxiation and their liver/intestines exposed through an incision around the upper abdomen. After clamping the duodenum wall to block the bile path, pancreas was slowly perfused and distended with 10\% (vol/vol) heat-inactivated fetal bovine serum (FBS)RPMI/antibiotics through the common bile duct. Then, pancreas was removed and digested in a plastic tube in HBSS-collagenase XI $(1 \mathrm{U} / \mu \mathrm{l})$ for $15 \mathrm{~min}$ at $37.5{ }^{\circ} \mathrm{C}$. Digestion was stopped by placing the digestion reaction on ice and by adding cold $1 \mathrm{mM} \mathrm{CaCl}_{2}-\mathrm{HBSS}$. Islets were 
washed by gentle centrifugation $\left(250 \mathrm{~g}, 30 \mathrm{~s}, 4{ }^{\circ} \mathrm{C}\right)$, resuspended in cold $1 \mathrm{mM} \mathrm{CaCl}-\mathrm{HBSS}$ and placed in a pre-wetted cell strainer $(70 \mu \mathrm{m}, \mathrm{BD}-\mathrm{Falcon}$, San Jose, CA, USA). Purified islets were rinsed off the restrainer onto a sterile Petri dish where islets were picked using a pipette with a wide-open tip. Islets were immediately plated and allowed to attach for $24-36 \mathrm{~h}$ in supplemented RPMI. Insulin secretion from islets was performed using an ultrasensitive ELISA kit (ALPCO Immunoassays, Salem, NH, USA) following manufacturer's instructions and the conditions indicated below.

\section{INS-1E $\beta$-cell culture}

Rat INS-1E cells were maintained following the original protocol (Merglen et al. 2004). Briefly, INS-1E $\beta$-cells were grown in RPMI $1640(11.1 \mathrm{mM}$ glucose), supplemented with $10 \mathrm{mM}$ HEPES, $2 \mathrm{mM}$ L-glutamine, $1 \mathrm{mM}$ sodium pyruvate, $50 \mu \mathrm{M} \beta$-mercaptoethanol, 10\% (vol/vol) FBS, $100 \mathrm{IU} / \mathrm{ml}$ penicillin and $100 \mu \mathrm{g} / \mathrm{ml}$ streptomycin. Cells were grown in $5 \% \mathrm{CO}_{2}$ at $37^{\circ} \mathrm{C}$ and media changed every 2-3 days until confluence.

\section{Insulin secretion}

Secretion of insulin from INS-1E cells or islets to the culture media was estimated essentially as described (Merglen et al. 2004). Briefly, INS-1E $\beta$-cells were plated in 12-well plates $\left(5 \times 10^{5}\right.$ cells/well) or six-well plates in the case of islets. Purified islets from a single mouse pancreas of each genotype were used at equivalent numbers per well and were cultured in complete media. Before glucose stimulation, islets and INS-1E cells were incubated overnight or for $2 \mathrm{~h}$ respectively in glucose-free RPMI media. On the day of the assay, attached cells per islets were washed three times with sterile glucose-free Krebs-Ringer bicarbonate-HEPES buffer (KRBH: $135 \mathrm{mM} \mathrm{NaCl}, 3.6 \mathrm{mM} \mathrm{KCl}, 5 \mathrm{mM}$ $\mathrm{NaHCO}_{3}, 0.5 \mathrm{mM} \mathrm{NaH} \mathrm{PO}_{4}, 0.5 \mathrm{mM} \mathrm{MgCl}, 1.5 \mathrm{mM}$ $\mathrm{CaCl}_{2}, 10 \mathrm{mM}$ HEPES $\mathrm{pH} 7 \cdot 4$ and $0 \cdot 1 \%$ ) and incubated in $\mathrm{KRBH}$ supplemented with several concentrations of glucose and BTD $(10 \mu \mathrm{M})$ or BTD's vehicle $(\mathrm{NaOH} 0 \cdot 1 \%)$. After $1 \mathrm{~h}$, supernatants were collected and stored at $-80{ }^{\circ} \mathrm{C}$ for later determination of insulin concentration.

\section{Insulinaemia}

Insulin was determined in plasma samples obtained from mice after $16 \mathrm{~h}$ of food deprivation (basal) and after a single i.p. injection of glucose $(3 \mathrm{~g} / \mathrm{kg} \mathrm{BW})$. Blood $(50 \mu \mathrm{l})$ was collected using heparinised capillary tubes (Scientific Glass, Inc., Rockwood, TN, USA) at time zero or after $10 \mathrm{~min}$ postglucose injection. Blood was placed in PCR tubes on ice and centrifuged at $10000 \boldsymbol{g}$ to collect plasma. Plasma was stored at $-80{ }^{\circ} \mathrm{C}$ until use. Plasma insulin or insulin present in culture media were quantitated by ELISA.

\section{Intraperitoneal glucose and insulin tolerance tests}

Glucose homeostasis in mice was evaluated following NIH's recommendations (McGuinness et al. 2009). Glycaemia was determined using a glucometer (FreeStyle-Lite, Abbott). Glucose tolerance test (GTT) and insulin tolerance test (ITT) were performed by i.p. administration of $2 \mathrm{~g} / \mathrm{kg}$ Dglucose or $0.75 \mathrm{U} / \mathrm{kg}$ human recombinant insulin (Humu$\operatorname{lin}^{\mathrm{R}}$ Eli Lilly \& Co.) respectively to mice fasted $16 \mathrm{~h}$. Glycaemia during GTTs was determined by blood sampling from the tip of the tail $0,5,10,15,30,45,60,90$ and $120 \mathrm{~min}$ after glucose injection. Glycaemia during ITTs was determined $0,5,10,15,30,45$ and $60 \mathrm{~min}$ post-insulin injection. The effect of $50 \mathrm{mg} / \mathrm{kg}$ BTD (Sigma) on glucose tolerance was tested after i.p. injection of $10 \mu \mathrm{l} / 10 \mathrm{~g}$ body weight of the drug dissolved in $0.1 \%(\mathrm{w} / \mathrm{v}) \mathrm{NaOH}$ at a final concentration of $5 \mathrm{mg} / \mathrm{ml}(13.7 \mathrm{mM})$.

\section{Immunofluorescence}

INS-1E cells in culture or tissue sections were processed essentially as described elsewhere for other cells (Di Fulvio et al. 2007) and adapted to insulin-secreting $\beta$-cells (Alshahrani \& Di Fulvio 2012). Briefly, semi-confluent INS-1E cells growing in glass coverslips for neural cell cultures (EMS, Hatfield, PA, USA) were carefully washed three times with $\mathrm{KRBH}$ and incubated for an hour in this buffer before fixation with absolute methanol at $-20{ }^{\circ} \mathrm{C}$ for $15 \mathrm{~min}$. Fixed cells or deparaffinised tissue slides were permeabilised using fresh $4 \% p$-formaldehyde plus $0 \cdot 25 \%$ Triton X-100 at room temperature for $0.5 \mathrm{~h}$. Cells/ sections were then incubated $2 \mathrm{~h}$ at $4{ }^{\circ} \mathrm{C}$ in PBS containing $3 \%$ serum (PBS-S). Fixed and permeabilised cells/slides were incubated with gentle rocking overnight at $4{ }^{\circ} \mathrm{C}$ in PBS-S containing primary antibodies (NKCC1, 1:1000; NKCC2, 1:500; pro-insulin, 1:500). After washing off primary antibodies, labelled cells/sections were incubated for $1 \mathrm{~h}$ at $4{ }^{\circ} \mathrm{C}$ with secondary antibodies (Cy3 or FITC conjugated $(1: 1000))$. Cells or tissue sections were washed three times with PBS and mounted using $20 \mu \mathrm{l}$ Vectashield (Vector Labs, Burlingame, CA, USA) containing DAPI to counterstain the cells' nuclei. Slides were viewed using an Olympus Epi Fluorescence microscope with RT colour camera, $60 \times$ or $100 \times$ oil objectives and proper fluorescence filters. Photomicrographs were obtained using a Diagnostics Instrument Spot 6 digital camera and MetaVue Software (Molecular Devices, Sunnyvale, CA, USA).

\section{Morphometric analysis of islets}

$\beta$-Cell number was computed using NIH Image J1.42G Software (rsbweb.nih.gov/ij/index.html_). Pancreas slides of $\mathrm{NKCC} 1^{\mathrm{WT}}$ and $\mathrm{NKCC} 1^{\mathrm{KO}}$ mice were immunostained using guinea pig polyclonal antibodies against insulin coupled to HRP-conjugated secondary antibodies (DermPrep, Tampa, FL, USA). Immunostained sections were visualised 
in a microscope and high-resolution images were taken at low magnification $(200 \times)$ or using oil immersion objectives $(600 \times)$. Digital pictures were analysed as described (Tchoukalova et al. 2003, Abramoff 2004). Insulin-positive cells were counted using the cell counter plugin of Image $J$ and related to the total cell count per islet in the slides, i.e. $\% \beta$-cells/islet. The volume of $\beta$-cells was also calculated from measured diameters $(d)$ in micrometer and then converted to picoliter assuming that $\beta$-cells are spheres with a volume $=3 / 4 \pi r^{3}$ in $\mu^{3}{ }^{3}$, where $1000 \mu \mathrm{m}^{3}=$ picoliters (Majid et al. 2001).

\section{Statistical analysis}

Data are expressed as mean \pm s.E.M. The difference between the means of two populations was determined using Student's two-tailed $t$-test after a preliminary $F$-test to determine homogeneity of within-group variances. The differences and significances in glycaemia or insulinaemia between more than two groups were determined using one-way ANOVA (GraphPad Prism Software, San Diego, CA, USA). The trapezoidal method was used to calculate the area under the curve (AUC; $\mathrm{mM} / \mathrm{min}$ ) of GTTs. The homeostatic model assessment (HOMA), an index of whole body insulin resistance, was calculated from fasting insulinaemia in $\mu \mathrm{U} / \mathrm{ml}(\mathrm{ng} / \mathrm{ml} \times 28 \cdot 6=\mu \mathrm{U} / \mathrm{ml})$ and glycaemia in $\mathrm{mM}\left(\mathrm{mg} / \mathrm{dl} \times^{1} /{ }_{18}=\mathrm{mM}\right)$ using the relationship HOMA $=($ insulin $) \times($ glucose $) / 22.5$. A $P<0.05$ was considered significant.

\section{Results}

The Slc12a2 gene impacts insulin release and glycaemia in vivo

NKCC1 has been proposed as a transport mechanism involved in maintaining $\left[\mathrm{Cl}^{-}\right]_{\mathrm{i}}$ above electrochemical equilibrium in $\beta$-cells (Eberhardson et al. 2000, Majid et al. 2001). Therefore, to directly determine the impact of NKCC1 in insulin secretion in vivo, we used mice harbouring homozygous inactivation of the Slc12a2 gene $\left(\mathrm{NKCC}^{\mathrm{KO}}\right)$. Basal plasma levels of insulin and glycaemia were determined in WT $\left(\mathrm{NKCC} 1^{\mathrm{WT}}\right.$ ) and $\mathrm{NKCC} 1^{\mathrm{KO}}$ mice after an overnight period of food deprivation $(16 \mathrm{~h})$. As shown in Fig. 1A, plasma insulin concentration in $\mathrm{NKCC}^{\mathrm{KO}}$ was significantly lower that that of $\mathrm{NKCC} 1^{\mathrm{WT}}$ mice $\left({ }^{*} \mathrm{P}<0 \cdot 05\right)$. Interestingly, low fasting insulinaemia correlated with low fasting glycaemia in NKCC1 mice, but not to the same extent (Fig. 1B). Indeed, the fasting glucose-to-insulin ratio in $\mathrm{NKCC} 1^{\mathrm{KO}}$ mice was $\sim 2.3$ times lower than that of $\mathrm{NKCC}^{\mathrm{WT}}$ mice, suggesting that $\mathrm{NKCC}^{\mathrm{KO}}$ may require less insulin than $\mathrm{NKCC} 1^{\mathrm{WT}}$ mice to maintain normoglycaemia. In agreement, the HOMA index calculated for $\mathrm{NKCC}^{\mathrm{KO}}$ was approximately ten times lower than that of $\mathrm{NKCC} 1{ }^{\mathrm{WT}}$ mice $\left(\mathrm{HOMA}^{\mathrm{KO}}=0.4\right.$ and $\left.\mathrm{HOMA}^{\mathrm{WT}}=4 \cdot 3\right)$, suggesting that $\mathrm{NKCC} 1^{\mathrm{KO}}$ mice are more sensitive to insulin than $\mathrm{NKCC} 1^{\mathrm{WT}}$. To corroborate this, insulin-induced
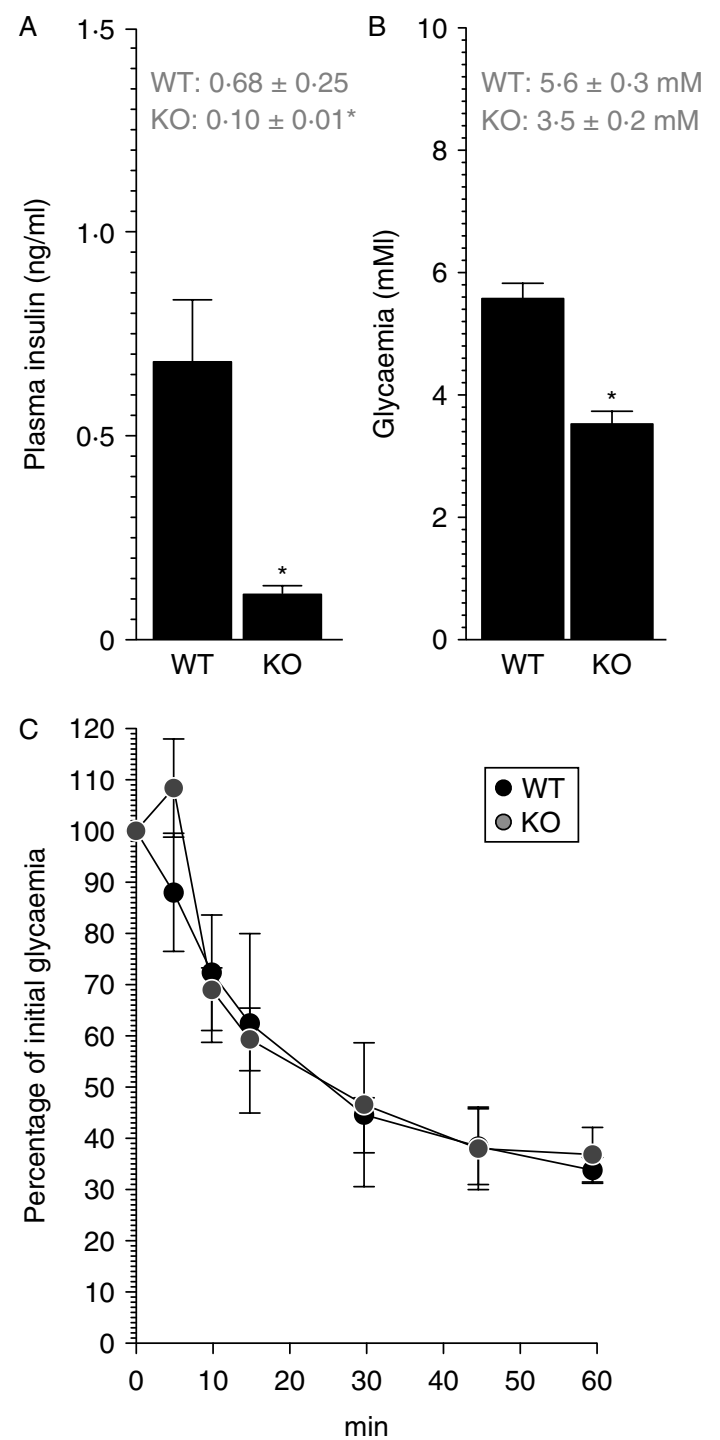

Figure 1 Insulinaemia and glycaemia in NKCC1 mice. (A) Plasma concentration of insulin in fasted NKCC 1 WT and $\mathrm{NKCC} 1^{\mathrm{KO}}$ mice. Shown are insulin values as nanograms per milliliter determined for each genotype. Results are the mean \pm S.E.M., $n=7$. Actual values are indicated on top of the bars $(* P<0 \cdot 05)$. (B) Blood glucose concentration in fasted mice of WT and KO genotypes $(n \geq 14$ for each genotype). Glycaemia values are the mean \pm s.E.M. (mM). Actual values are indicated on top of the bars $(* P<0 \cdot 001)$. (C) Insulin-induced hypoglycaemia in fasted $\mathrm{NKCC} 1^{\mathrm{WT}}$ and NKCC $1^{\mathrm{KO}}$ mice (black and grey circles respectively). Results are plotted as percentage drop of initial glycaemia, i.e. before insulin injection vs time in minutes. Initial glycaemia for each genotype was NKCC $1^{\mathrm{WT}}, 5 \cdot 9 \pm 0 \cdot 5 \mathrm{mM}$ and NKCC $1^{\mathrm{KO}}, 3 \cdot 9 \pm 0 \cdot 4 \mathrm{mM}(n=6)$.

hypoglycaemia was determined in $\mathrm{NKCC} 1^{\mathrm{WT}}$ and NKCC1 ${ }^{\mathrm{KO}}$ mice after a single dose of insulin (i.p. $0 \cdot 75 \mathrm{U} /$ $\mathrm{kg})$. Notably, ITTs were not significantly different in NKCC1 mice of either genotype (Fig. 1C), indicating that $\mathrm{NKCC}^{\mathrm{KO}}$ and $\mathrm{NKCC} 1^{\mathrm{WT}}$ mice are equally sensitive to exogenously administered insulin. 
The Slc12a 2 gene impacts insulin release in response to glucose in vivo and in vitro

To determine the role of NKCC1 on insulin secretion in vivo, NKCC $1^{\mathrm{WT}}$ and $\mathrm{NKCC} 1^{\mathrm{KO}}$ mice were treated with a single dose of D-glucose (i.p. $3 \mathrm{~g} / \mathrm{kg}$ ) and plasma insulin concentration was determined 10 min post-injection. As shown in Fig. 2A, plasma insulin levels increased after a load of glucose; however, the mean insulin response of $\mathrm{NKCC}^{\mathrm{KO}}$ was significantly higher than that of $\mathrm{NKCC} 1^{\mathrm{WT}}$ mice, suggesting that $\beta$-cells lacking NKCC1 are more sensitive to glucose than $\beta$-cells expressing both alleles of the co-transporter.

To confirm these in vivo findings, insulin secretion from islets of both genotypes, i.e. $\mathrm{NKCC} 1^{\mathrm{KO}}$ and $\mathrm{NKCC} 1^{\mathrm{WT}}$, was determined after challenging them with low, normal or high insulinotropic concentrations of glucose $(2 \cdot 5,5 \cdot 5$ and $20 \mathrm{mM}$ respectively). As shown in Fig. 2B, the secretory response of islets to $5.5 \mathrm{mM}$ glucose, a concentration not expected to provoke insulin secretion from islets, significantly increased insulin secretion from islets lacking NKCC1 (Fig. 2B, black bars). Notably, $20 \mathrm{mM}$ glucose increased insulin secretion from islets of both genotypes in a similar extent relative to $5.5 \mathrm{mM}$ (Fig. 2B, grey bars), but the fold increases were higher from islets lacking NKCC1. Taken together, our results suggest that the Slc12a2 gene is not necessary for insulin secretion and that functional elimination of this gene sensitises $\beta$-cells to the action of glucose.
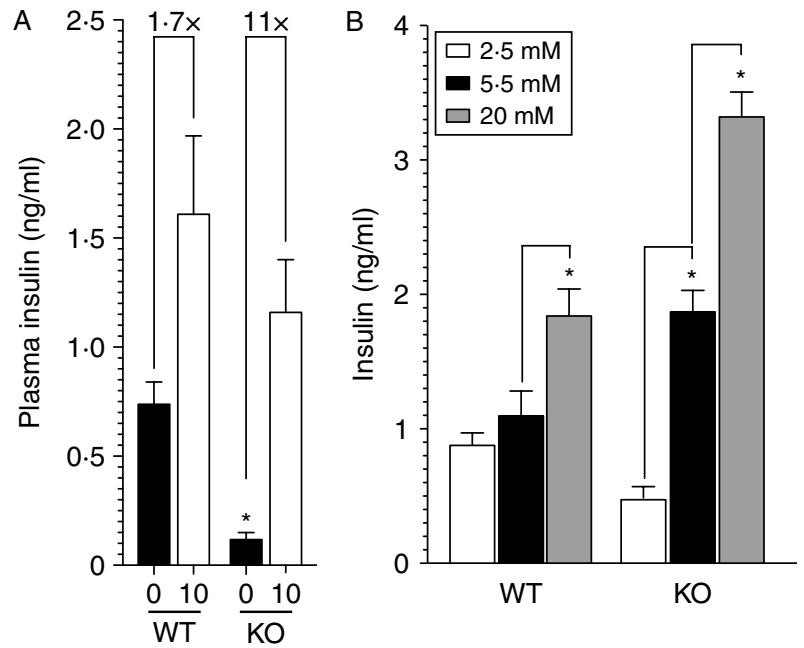

Figure 2 Insulin response of mice and islets lacking NKCC1. (A) Plasma insulin levels at baseline (black bars) and 10 min postglucose administration (white bars). Results are expressed as nanograms of insulin per milliliter of plasma $\left({ }^{*} P<0 \cdot 001, n=6\right)$. The fold-increment $(X)$ in insulin responses for each genotype is indicated on top of each grouped bars. (B) Insulin secretion in vitro from primary cultures of pancreatic islets obtained from NKCC $1^{\mathrm{WT}}$ and NKCC1 ${ }^{\mathrm{KO}}$ mice challenged with different glucose concentrations: $2.5 \mathrm{mM}$ (white bar), $5.5 \mathrm{mM}$ (black bar) and $20 \mathrm{mM}$ (grey bar). Shown are representative experiments from equivalent numbers of islets of both genotypes. Results are expressed as nanograms per milliliter of insulin (mean \pm S.E.M., $n=5, * P<0 \cdot 05$ ) present in the culture media $1 \mathrm{~h}$ post-challenge.
NKCC $1^{K O}$ mice exhibit improved glucose tolerance

To determine whether increased glucose-induced insulin secretion correlates with enhanced glucose tolerance in vivo, NKCC1 mice were subjected to GTTs. As shown in Fig. 3A, mean glucose levels are significantly lower in $\mathrm{NKCC}^{\mathrm{KO}}$ when compared with those of NKCC $1{ }^{\mathrm{WT}}$ mice at each time point during the GTTs. As glucose tolerance in mice is influenced by their genetic backgrounds (Kaku et al. 1988, Toye et al. 2005), 129/SvJ NKCC $1^{\mathrm{KO}}$ and $\mathrm{NKCC} 1^{\mathrm{WT}}$ mice were subjected to GTTs after an overnight fasting period. As shown in Fig. 3B, GTTs of 129/SvJ mice of each genotype were not significantly different from those of the C57BL/6J background. This is illustrated by the calculated areas under each GTT curve (AUC; $\mathrm{mmol} / \mathrm{min}$ per $\mathrm{l}$ ), a parameter reflecting insulin mobilisation and/or sensitivity, and inversely proportional to glucose clearance. As shown in Fig. 3C, $\mathrm{AUC}^{\mathrm{KO}}$ is significantly different from $\mathrm{AUC} \mathrm{WT}^{\mathrm{WT}}$, irrespective of genetic background, indicating that absence of NKCC1 improves glucose tolerance in C57BL/6J and 129/SvJ mice. Therefore, our results suggest that $\mathrm{NKCC} 1^{\mathrm{KO}}$ mice have increased glucose tolerance due to enhanced glucose-induced insulin secretion and that this phenomenon does not depend on genetic background.

Homozygous inactivation of the Slc12a 2 gene increases $\beta$-cell mass

The demonstrated changes in glucose homeostasis in $\mathrm{NKCC} 1^{\mathrm{KO}}$ mice could be explained, at least in part, by increased pancreatic $\beta$-cell mass. To ascertain this, the $\beta$-cell number per islets and the number of islets within the pancreas were analysed morphometrically in tissue sections immunostained against insulin. As shown in Fig. 4A and B, the number of $\beta$-cells per islet appears to be higher in $\mathrm{NKCC}^{\mathrm{KO}}$ when compared with $\mathrm{NKCC} 1^{\mathrm{WT}}$ mice. To evaluate the significance of this observation, insulin-positive cells per islet were counted using the NIH's Software package ImageJ. As shown in Fig. $4 \mathrm{C}$, the number of $\beta$-cells relative to the total cell count in islets was significantly higher in islets of $\mathrm{NKCC}^{\mathrm{KO}}$ mice when compared with NKCC1 ${ }^{\mathrm{WT}}(78 \pm 4$ and $62 \pm 6 \%$ $\beta$-cells/islet respectively, $\left.{ }^{*} P<0 \cdot 05\right)$. To determine whether the number of $\beta$-cells per islet correlate with reduced $\beta$-cell size, cross-sectional diameters of insulin-positive cells were estimated and used to compute cell volume, assuming them to be spheres. As predicted from the functional absence of NKCC1, a known regulator of cell volume, $\beta$-cells from $\mathrm{NKCC} 1^{\mathrm{KO}}$ mice showed a significant reduction in cell volume when compared with $\beta$-cells of NKCC1 ${ }^{\text {WT }}$ $\left(\mathrm{vol}_{\mathrm{WT}}=0.73 \pm 0.06 \mathrm{vs} \mathrm{vol}_{\mathrm{KO}}=0.45 \pm 0.03 \mathrm{pl}, n>100\right.$, ${ }^{*} P<0 \cdot 01$ ), suggesting that $\beta$-cells lacking NKCC1 underwent hyperplasia. To determine islet density in pancreas of $\mathrm{NKCC} 1^{\mathrm{KO}}$ and $\mathrm{NKCC} 1^{\mathrm{WT}}$ mice, the number of islets per $\mu \mathrm{m}^{2}$ of tissue was quantified on at least five different slides immunostained against insulin. As shown in Fig. 4F, islet density in both $\mathrm{NKCC} 1^{\mathrm{WT}}$ and $\mathrm{NKCC} 1^{\mathrm{KO}}$ mice was not 

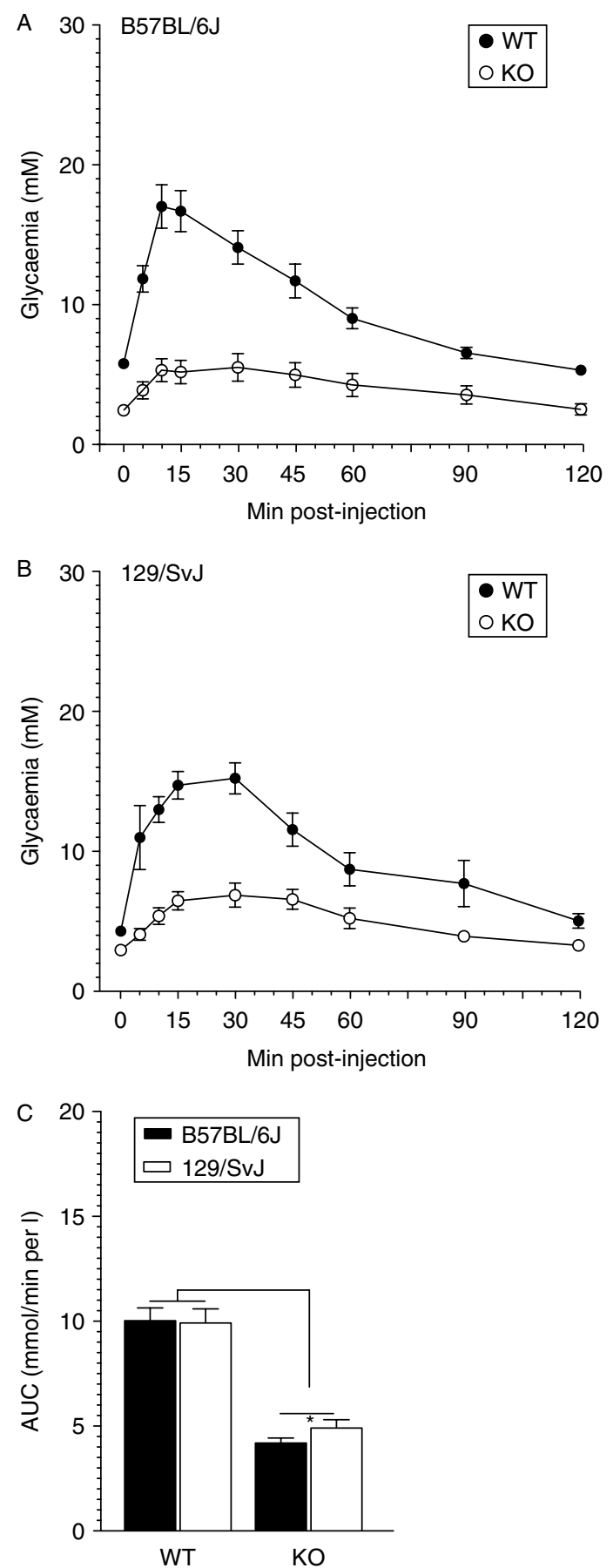

Figure 3 Glucose tolerance in $\mathrm{NKCC} 1^{\mathrm{KO}}$ mice. (A) Intraperitoneal GTTs performed in mice of the $\mathrm{B} 57 \mathrm{BL} / 6 \mathrm{~J}$ genetic background and genotypes NKCC1 ${ }^{\mathrm{WT}}$ (black circles, $n \geq 10$ ) or NKCC1 ${ }^{\text {RO }}$ (white circles, $n \geq 10$ ) fasted for $16 \mathrm{~h}$. (B) GTTs performed in fasted 129/Sv] mice of each genotype: NKCC ${ }^{\mathrm{WT}}$ (black circles, $n=9$ ) and NKCC $1^{\mathrm{KO}}$ (white circles, $n=10$ ). (C) AUCs of each GTT performed in $\mathrm{NKCC} 1^{\mathrm{WT}}$ and $\mathrm{NKCC} 1^{\mathrm{KO}}$ of each genetic background: $\mathrm{B} 57 \mathrm{BL} / 6$ ] (black bars) and 129/SvJ (white bars). AUCs were calculated using the trapezoidal method and are expressed as glycaemia in $\mathrm{mmol} / \mathrm{l}$ cleared from blood in $120 \mathrm{~min}\left({ }^{*} P<0 \cdot 001\right)$. statistically significant. However, the mean wet weight of $\mathrm{NKCC} 1^{\mathrm{KO}}$ pancreas was $\sim 50 \%$ lighter that that of NKCC1 ${ }^{\text {WT }}$ mice $(176 \pm 11$ and $326 \pm 18 \mathrm{mg}$ respectively). Similarly, total body weight of $\mathrm{NKCC} 1{ }^{\mathrm{WT}}$ and $\mathrm{NKCC} 1^{\mathrm{KO}}$ mice aging 20-23 days was $10 \cdot 9 \pm 0 \cdot 3 \mathrm{~g}(n=60)$ and $6 \cdot 0 \pm 0 \cdot 2 \mathrm{~g}(n=41)$ respectively. Hence, the ratio of pancreatic wet weight/body weight was not different in $\mathrm{NKCC} 1^{\mathrm{KO}}$ mice relative to $\mathrm{NKCC} 1^{\mathrm{WT}}$. Therefore, these results support the hypothesis that $\mathrm{NKCC} 1^{\mathrm{KO}}$ have higher insulin secretory reserve/capacity than $\mathrm{NKCC} 1^{\mathrm{WT}}$ mice due to an increased number of $\beta$-cells per islet, a finding consistent with the high insulin response to glucose and the consequent high glucose clearance observed in $\mathrm{NKCC}^{\mathrm{KO}}$ mice.

\section{BTD worsens glucose tolerance in $\mathrm{NKCC} 1^{\mathrm{KO}}$ mice}

The relevance of $\left[\mathrm{Cl}^{-}\right]_{\mathrm{i}}$ in $\beta$-cell physiology is established (Sehlin 1978, Somers et al. 1980, Tamagawa \& Henquin 1983, Lindstrom et al. 1986, Kinard \& Satin 1995, Eberhardson et al. 2000, Majid et al. 2001, Best 2005, Best et al. 2010). We have recently demonstrated that NKCC2 is expressed in $\beta$-cells, thus providing a potential additional mechanism for $\left[\mathrm{Cl}^{-}\right]_{\mathrm{i}}$ regulation in these cells (Alshahrani \& Di Fulvio 2012). To gain insights into the role of NKCC2 in insulin secretion, the impact of BTD on baseline glycaemia was tested in fasting $\mathrm{NKCC}^{\mathrm{WT}}$ and $\mathrm{NKCC} 1^{\mathrm{KO}}$ mice. To this end, mice were treated with a single low dose of BTD (i.p. $50 \mathrm{mg} / \mathrm{kg}$ ) $5 \mathrm{~min}$ before determination of baseline glycaemia. Figure $5 \mathrm{~A}$ shows that an acute dose of BTD significantly increases basal glycaemia in fasted $\mathrm{NKCC} 1^{\mathrm{WT}}$ but not in $\mathrm{NKCC}^{\mathrm{KO}}$ mice. Although these results are consistent with the notion that BTD targets NKCCs in $\beta$-cells, NKCC2 has different pharmacological and kinetic behaviours relative to NKCC1. Indeed, NKCC2 is less sensitive to BTD than NKCC1 $\left(\mathrm{IC}_{50}^{\mathrm{NKCC} 1}=0 \cdot 05-0 \cdot 1 \mu \mathrm{M} ; \mathrm{IC}_{50}^{\mathrm{NKCC} 2}=\sim 2-3 \mu \mathrm{M}\right.$; Gamba 2005), and both transporters exhibit different ion affinities and transport rates (Isenring et al. 1998, Gimenez \& Forbush 2007). Therefore, we examined the impact of a single dose of BTD on glucose tolerance. To this end, fasted NKCC $1^{\mathrm{KO}}$ and $\mathrm{NKCC} 1^{\mathrm{WT}}$ mice were subjected to GTTs $5 \mathrm{~min}$ after BTD administration (i.p. $50 \mathrm{mg} / \mathrm{kg}$ ). As shown in Fig. 5B, a single dose of BTD worsens glucose tolerance in both $\mathrm{NKCC} 1^{\mathrm{WT}}$ and $\mathrm{NKCC} 1^{\mathrm{KO}}$ mice (compare Figs $3 \mathrm{~A}$ and $5 \mathrm{~B})$. This effect is clearly visualised in Fig. 5C where the calculated AUCs for each GTT are shown. Similar results were obtained when $\mathrm{NKCC} 1^{\mathrm{KO}}$ and $\mathrm{NKCC} 1{ }^{\mathrm{WT}}$ mice of the 129/SvJ genetic background were tested (not shown). Together, these findings suggest that BTD impairs glucose tolerance in mice deficient in NKCC1, thus unmasking a potential new role for NKCC2 expressed in $\beta$-cells.

BTD inhibits glucose-induced insulin secretion from $\beta$-cells lines and $\mathrm{NKCC} 1^{\mathrm{KO}}$ islets

To confirm the role of BTD on glucose tolerance in vivo, the impact of the drug on glucose-stimulated insulin secretion 

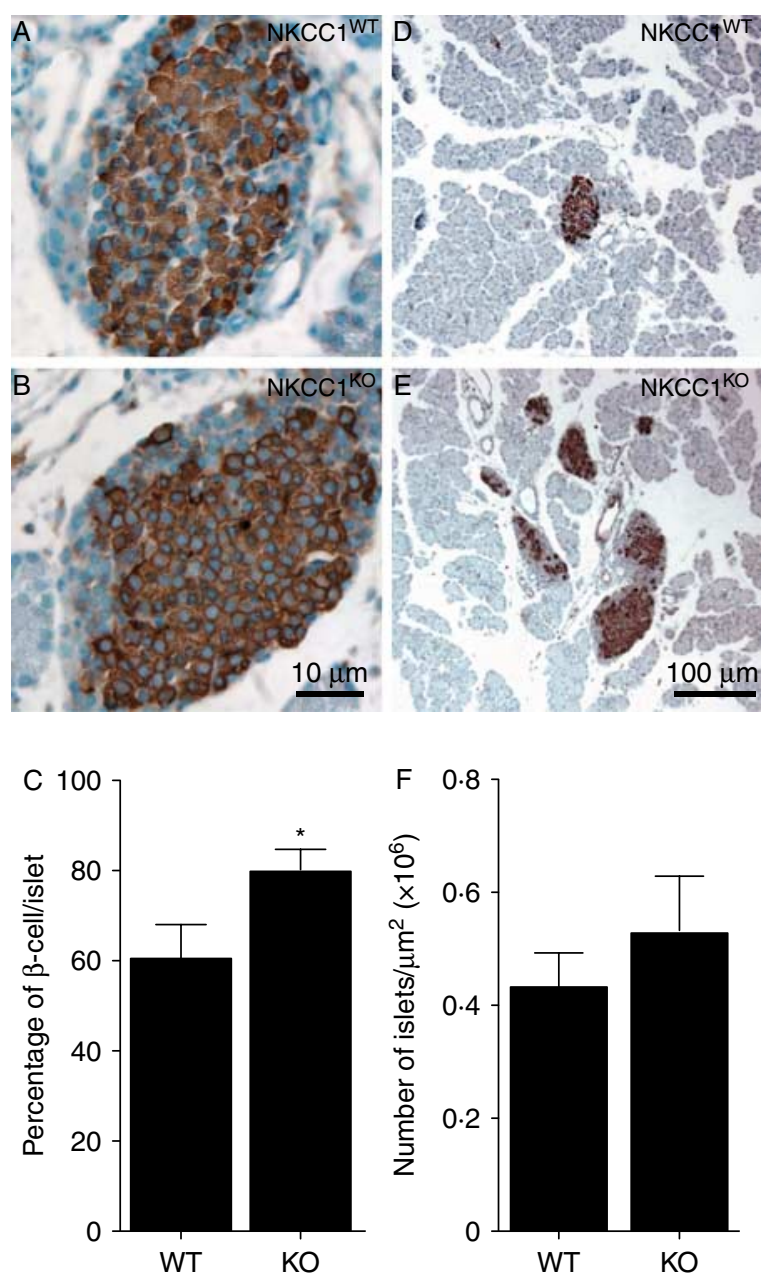

Figure $4 \beta$-Cell mass in $\mathrm{NKCC} 1^{\mathrm{KO}}$ mice. (A and $\mathrm{B}$ ) Immunohistochemistry of pancreas obtained from NKCC1 ${ }^{\mathrm{WT}}(\mathrm{A})$ and NKCC $1^{\mathrm{KO}}$ (B) mice littermates (post-natal age 21 days). Shown are representative images of insulin immunolabelled islets of similar diameter taken at high resolution $(600 \times)$. (C) The relative number of insulin-positive $\beta$-cells was morphometrically determined in slides immunostained against insulin using ImageJ. $\beta$-Cell number was related to the total cell count per islet. A minimum of 20 islets per genotype was analysed. Results are expressed as number of $\beta$-cells per islet $\left({ }^{*} P<0 \cdot 05\right)$. ( $\mathrm{D}$ and $\mathrm{E}$ ) Immunohistochemistry of pancreas obtained from NKCC1 ${ }^{\mathrm{WT}}(\mathrm{D})$ and $\mathrm{NKCC}^{\mathrm{KO}}(\mathrm{E})$ littermates (post-natal age 21 days) immunolabelled against insulin. Representative images of pancreas tissues taken at low magnification $(200 \times)$ where insulin-positive $\beta$-cells in several islets can be observed. (F) The number of islets in pancreas of NKCC $1^{\mathrm{WT}}$ or NKCC $1^{\mathrm{KO}}$ genotypes was manually quantified in at least five different immunostained slides from pancreas sections obtained more than $20 \mu \mathrm{m}$ apart.

was tested in vitro in cultures of INS-1E, a rat $\beta$-cell line known to secrete insulin in response to glucose (Merglen et al. 2004) and to express NKCC1 and NKCC2 (Alshahrani \& Di Fulvio 2012). As shown in Fig. 6A, $10 \mu \mathrm{M}$ BTD, a dose considered to inhibit both NKCC1 and NKCC2A in vitro (Gamba 2005), completely blocked insulin secretion in response to insulinotropic concentrations of glucose, suggesting that NKCCs, either 1 or 2, are involved in insulin secretion. To ascertain and corroborate that INS-1E cells express NKCC1 and NKCC2 and to minimise potential changes in gene expression due to different culture conditions, immunofluorescence experiments were performed on INS-1E $\beta$-cells growing under identical conditions as the ones used to determine insulin secretion. As shown in Fig. 6B, C, D and E, INS-1E $\beta$-cells co-express NKCC1 and NKCC2, suggesting that BTD acts on these two co-transporters to inhibit insulin secretion. To unmask the role of NKCC2 in insulin secretion, the effect of BTD on glucose-induced insulin secretion was tested in primary cultures of islets lacking NKCC1. As shown in Fig. 6B, the secretory response of primary cultures of $\mathrm{NKCC} 1^{\mathrm{KO}}$ islets challenged with low, normal or high glucose concentrations $(2 \cdot 5,5 \cdot 5$ and $20 \mathrm{mM}$ respectively) is blocked in the presence of $10 \mu \mathrm{M}$ BTD $\left({ }^{*} P<0 \cdot 05\right)$. To corroborate expression of NKCC2 in $\beta$-cells lacking NKCC1, slides of pancreas obtained from $\mathrm{NKCC} 1^{\mathrm{KO}}$ mice were immunostained against pro-insulin and NKCC2. As shown in Fig. 6G, H, I and J, NKCC2 and pro-insulin colocalise in islets of $\mathrm{NKCC}^{\mathrm{KO}}$ mice, in agreement with our previous data (Alshahrani \& Di Fulvio 2012). Taken together, our results suggest that BTD impairs glucose tolerance in $\mathrm{NKCC}^{\mathrm{KO}}$ mice by a direct effect on insulin secretion via inhibition of NKCC2.

\section{Discussion}

We have shown that mice lacking NKCC1, a co-transporter considered to play a key role in $\mathrm{Cl}^{-}$homeostasis in $\beta$-cells, exhibit lower basal insulinaemia, glycaemia (Fig. 1A and B) and a strong insulin response to glucose in vivo (Fig. 2) when compared with $\mathrm{NKCC} 1^{\mathrm{WT}}$ mice. It has been documented that post-weaned $\mathrm{NKCC} 1^{\mathrm{KO}}$ mice present gastrointestinal abnormalities and hypo-salivation, both conditions that may be related to the apparent growth retardation observed in these mice (Flagella et al. 1999). Therefore, inadequate caloric intake may explain the relatively low basal glycaemia and exaggerated insulin responses to glucose demonstrated in NKCC $1^{\mathrm{KO}}$ mice. However, our results were clearly not feedrelated; in one hand, autopsies of $\mathrm{NKCC}^{\mathrm{KO}}$ mice before/at weaning time always revealed amounts of milk in their stomachs comparable to NKCC ${ }^{\mathrm{WT}}$ littermates, and on the other hand, after weaning, they feed normally (data not shown). Interestingly, some weaned $\mathrm{NKCC} 1^{\mathrm{KO}}$ mice showed behavioural abnormalities such as tremor, food aggression and apparent hyperactivity, particularly after an overnight fasting period, consistent with symptoms of hypoglycaemia. In fact, some $\mathrm{NKCC} 1^{\mathrm{KO}}$ mice had very low glycaemia after an overnight fasting period $(1 \cdot 5-2 \cdot 2 \mathrm{mM})$. These results suggest that insulin secretion may not be reduced in $\mathrm{NKCC} 1^{\mathrm{KO}}$ mice, as it could be expected from the absence of NKCC1 and the demonstrated dependency that insulin secretion has on $\left[\mathrm{Cl}^{-}\right]_{\mathrm{i}}$ (Sehlin 1978, Best 2005). 

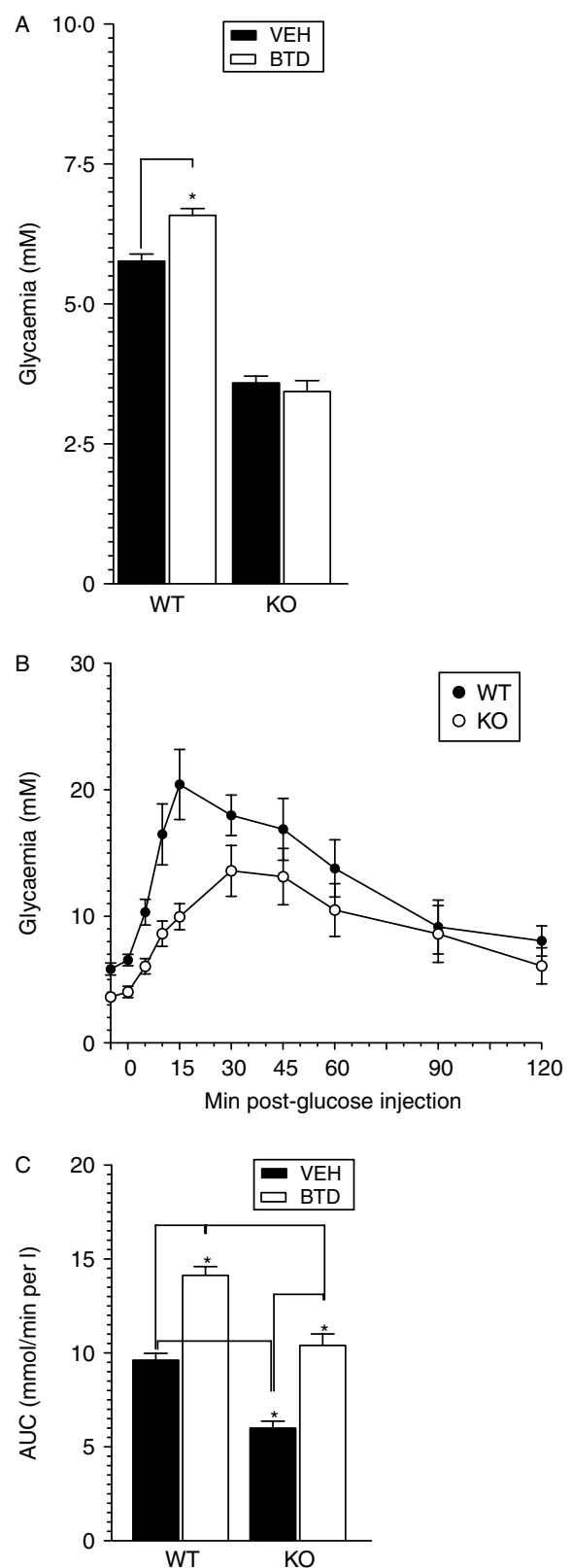

Figure 5 Impact of BTD on glucose tolerance in $\mathrm{NKCC}^{\mathrm{KO}}$ mice. (A) Effect of an acute low dose of BTD on basal blood glucose. Glycaemia was determined in fasted NKCC ${ }^{\mathrm{WT}}(n=8)$ and NKCC $1^{\mathrm{KO}}$ mice $(n=7) 5$ min after injection of vehicle $(\mathrm{NaOH}$ $0 \cdot 1 \%$, black bars) or BTD (white bars, $50 \mathrm{mg} / \mathrm{kg}$ ). Asterisk $(*)$ represents statistical significance $(P<0 \cdot 01)$. (B) Intraperitoneal GTT performed in fasted NKCC1 mice of each genotype: NKCC1 ${ }^{\mathrm{WT}}$ (black circles, $n=9$ ) and NKCC1 ${ }^{\mathrm{KO}}$ (white circles, $\left.n=7\right)$. (C) AUCs of each GTT performed in NKCC $1^{\mathrm{WT}}$ and $\mathrm{NKCC} 1^{\mathrm{KO}}$ mice injected with vehicle (black bars, $\mathrm{NaOH} 0 \cdot 1 \%, n=6$ in each genotype group) or BTD (50 mg/kg, white bars, from B) 5 min before injection of glucose $(2 \mathrm{~g} / \mathrm{kg})$. AUCs were calculated using the trapezoidal method and are expressed as glycaemia in $\mathrm{mmol} / \mathrm{l}$ cleared from blood in $120 \mathrm{~min}\left({ }^{*} P<0 \cdot 01\right)$.
Our results do not appear to be related to increased insulin sensitivity of peripheral tissues to insulin (Fig. 1C) but rather to increased sensitivity of $\beta$-cells to glucose. In fact, $\mathrm{NKCC} 1^{\mathrm{KO}}$ mice had a robust insulin response to glucose when compared with $\mathrm{NKCC}^{\mathrm{WT}}$ mice (Fig. $2 \mathrm{~A}$ ). It can be argued that the increased insulin secretion demonstrated in $\mathrm{NKCC} 1^{\mathrm{KO}}$ mice is due to hyperkalaemia, a known condition of $\mathrm{NKCC} 1^{\mathrm{KO}}$ mice (Wall et al. 2006). However, $\mathrm{NKCC} 1^{\mathrm{KO}}$ were hypoinsulinaemic when compared to $\mathrm{NKCC}^{\mathrm{WT}}$ mice (Fig. 1A) and identical insulinotropic concentrations of glucose produced a higher stimulatory response in islets of NKCC $1^{\mathrm{KO}}$ mice when compared with $\mathrm{NKCC} 1^{\mathrm{WT}}$ (Fig. 2B). Moreover, $\mathrm{NKCC}^{\mathrm{KO}}$ mice exhibited a relatively flat glucose tolerance (Fig. 3) in the presence of normal overall tissue sensitivity to insulin (Fig. 1C). It has been suggested that glucose tolerance in mice depends on their genetic background (Kaku et al. 1988). However, increased glucose tolerance in $\mathrm{NKCC} 1^{\mathrm{KO}} \mathrm{B} 57 \mathrm{BL} / 6 \mathrm{~J}$ mice was also demonstrated in $129 / \mathrm{SvJ}$ NKCC $1^{\mathrm{KO}}$ mice (Fig. 3), thus suggesting that low glycaemia, insulinaemia and improved glucose tolerance in $\mathrm{NKCC} 1^{\mathrm{KO}}$ mice may be the result of increased sensitivity of $\beta$-cells to glucose due to absence of NKCC1. Therefore, our results support the concept that NKCC1 expression is not necessary for insulin secretion.

Insulin secretion also depends on $\beta$-cell mass and pancreatic $\beta$-cell mass depends on the rates of $\beta$-cell generation, growth, duplication, size and apoptosis (Bouwens \& Rooman 2005), parameters known to be directly or indirectly influenced by NKCC activity in different cell types (Hoffmann et al. 2009, Cuddapah \& Sontheimer 2011). We found that the $\beta$-cell number in $\mathrm{NKCC} 1{ }^{\mathrm{KO}}$ mice was significantly higher than that of $\mathrm{NKCC}^{\mathrm{WT}}$ (Fig. 4A, B and C). This finding appears to be related to high $\beta$-cell density as $\beta$-cell size was smaller in $\mathrm{NKCC}^{\mathrm{KO}}$ islets than those of $\mathrm{NKCC} 1^{\mathrm{WT}}$ (Fig. 4A, B and $\mathrm{C})$. Further, the mean NKCC1 ${ }^{\mathrm{WT}} \beta$-cell size estimation was in close proximity to that already determined for mice of similar post-natal ages using pancreas slides (Herbach et al. 2011) or dispersed cells (Barg et al. 2000). Therefore, our findings are physiologically significant and support the notion that the high glucose clearance phenotype demonstrated in NKCC1 ${ }^{\mathrm{KO}}$ mice may be related to increased insulin reserve due to increased $\beta$-cell mass.

Although the mechanisms involved in proliferation of $\beta$-cells lacking NKCC1 remain unknown, our findings are in contrast to the direct positive linear relationship that exists between $\beta$-cell mass and body weight (Montanya et al. 2000, Herbach et al. 2011) and to the known negative impact that pharmacological inhibition of NKCC1 or depletion of $\left[\mathrm{Cl}^{-}\right]_{i}$ have on normal cell growth and proliferation (O'Brien et al. 1988, Panet et al. 1994, 2000, 2002, Lang et al. 1998, Iwamoto et al. 2004, Shiozaki et al. 2006). Indeed, $\mathrm{NKCC}^{\mathrm{KO}}$ mice are half the weight of NKCC1 ${ }^{\text {WT }}$ littermates (Flagella et al. 1999) and reduction of $\left[\mathrm{Cl}^{-}\right]_{\mathrm{i}}$ inhibits cell proliferation by blocking cell cycle transition from G1 to the S phase (Ohsawa et al. 2010). Hence, increased glucose-induced insulin secretion and high $\beta$-cell mass cannot be explained by $\left[\mathrm{Cl}^{-}\right]_{\mathrm{i}}$ at 

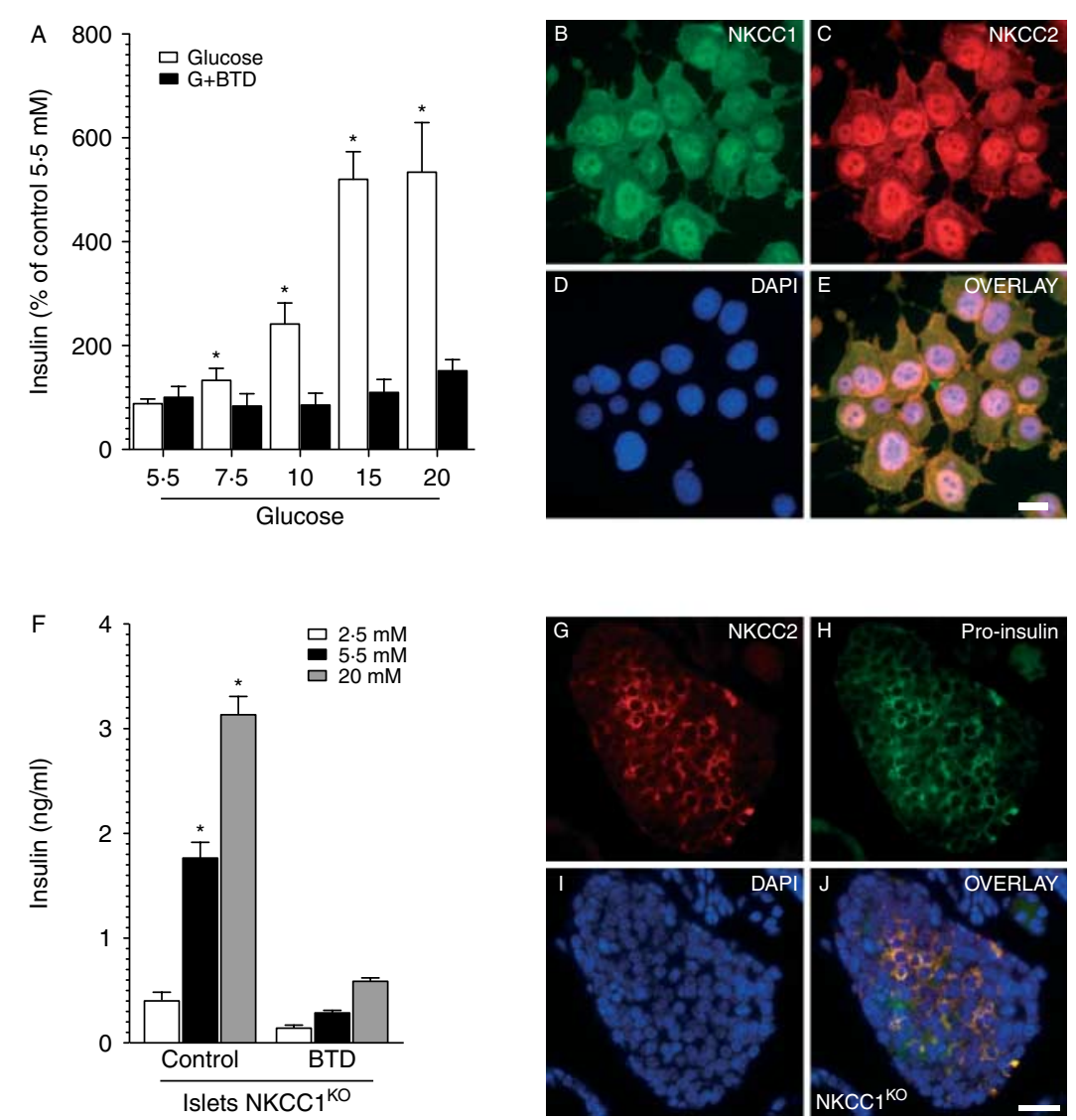

Figure 6 Effect of BTD on insulin secretion in vitro in $\beta$-cells and islets lacking NKCC1. (A) Effect of BTD on glucose-stimulated insulin secretion in the rat $\beta$-cell line INS-1E. Cells $\left(10^{5} /\right.$ well $)$ were incubated in the presence of the indicated concentrations of glucose $(5 \cdot 5-20 \mathrm{mM})+$ vehicle $(\mathrm{NaOH} 0 \cdot 1 \%$, white bars) or + BTD $(10 \mu \mathrm{M}$, black bars). Insulin secretion was determined $1 \mathrm{~h}$ post-challenge in dilutions of the culture media using an ultrasensitive ELISA. Results are the mean \pm S.E.M. from six different experiments and are expressed relative to initial insulin values obtained at $5.5 \mathrm{mM}$ glucose (there was no significant difference between insulin secretion evoked by 2.5 and $5.5 \mathrm{mM}$ glucose, as previously demonstrated by Merglen et al. (2004)). (B, C, D and E) Representative indirect immunofluorescence of INS-1E $\beta$-cells grown on glass coverslips. Cells were co-immunolabelled using a monoclonal antibody directed against human NKCC1 (B) and rabbit polyclonal antibodies against rat NKCC2 (C). FITC- and Cy3-conjugated secondary antibodies were used to label NKCC1 and NKCC2 respectively whereas nuclei were counterstained using DAPI (D). The overlay of micrographs (B, C and D) is shown in (E). Bar represents $10 \mu \mathrm{m}$. (F) Insulin secretion in vitro from primary cultures of pancreatic islets obtained from NKCC $1^{\mathrm{KO}}$ mice challenged with different glucose concentrations:

$2.5 \mathrm{mM}$ (white bar), $5.5 \mathrm{mM}$ (black bar) or $20 \mathrm{mM}$ (grey bar) plus vehicle $(\mathrm{NaOH}, 0 \cdot 1 \%$ ) or $10 \mu \mathrm{M}$ BTD. Results are representative of three experiments performed in triplicate and are expressed as nanograms per milliliter insulin (mean \pm s.E.M.) secreted $1 \mathrm{~h}$ post-challenge from equivalent number of islets $(* P<0 \cdot 05)$. $(\mathrm{G}, \mathrm{H}, \mathrm{I}$ and $\mathrm{J})$ NKCC2 $(\mathrm{G})$ and pro-insulin $(\mathrm{H})$ localisation in islets of $\mathrm{NKCC} 1^{\mathrm{KO}}$ mice. Slides were $\mathrm{CO}$-immunostained using monoclonal antibodies directed against pro-insulin and anti-NKCC2 antibodies. FITC- and Cy3conjugated secondary antibodies were used to label pro-insulin and NKCC2, respectively, whereas nuclei $(\mathrm{I})$ were counterstained using DAPI. The overlay of micrographs $(\mathrm{G}, \mathrm{H}$ and $\mathrm{I}$ ) is shown in (J). Bar represents $10 \mu \mathrm{m}$.

electrochemical equilibrium due to the functional absence of NKCC1. Therefore, additional transport mechanisms regulating $\left[\mathrm{Cl}^{-}\right]_{\mathrm{i}}$ may exist in $\beta$-cells (Eberhardson et al. 2000). Consistent with this notion, we have recently shown that $\beta$-cells express NKCC2A, a specific splice variant of the co-transporter known to be functionally up-regulated by cell shrinkage or low $\left[\mathrm{Cl}^{-}\right]_{\mathrm{i}}(\mathrm{Gamba} 2005)$, conditions that can be recapitulated by chronic depletion of functional NKCC1 in 
$\beta$-cells (Fig. 4A, B and C). Therefore, our findings may place NKCC2A as a compensatory mechanism involved in insulin secretion in the absence of NKCC1.

The involvement of NKCC2A in insulin secretion is suggested by the finding that $\mathrm{BTD}$, a specific inhibitor of NKCC1 and NKCC2, impaired glucose tolerance in NKCC $1^{\mathrm{WT}}$ mice and in INS-1E $\beta$-cells (Figs $5 \mathrm{~B}$ and $6 \mathrm{~A}$ respectively). Further, INS-1E cells express NKCC1 and NKCC2 under the experimental conditions where insulin secretion was stimulated by glucose but inhibited by BTD (Fig. 6B, C, D and E). Hence, BTD may inhibit insulin secretion by a direct effect on NKCC1 and NKCC2. Interestingly, BTD increased basal glycaemia in NKCC1 ${ }^{\mathrm{WT}}$ but not in NKCC1 ${ }^{\mathrm{KO}}$ mice (Fig. 5A). These results are in line with the notion that NKCC1 is more abundant than NKCC2 in $\beta$-cells (Alshahrani \& Di Fulvio 2012) and that NKCC1 is more sensitive to BTD than NKCC2 (Gamba 2005). Therefore, insulin secretion may be impaired in $\mathrm{NKCC} 1{ }^{\mathrm{WT}}$ mainly as a result of NKCC1 inhibition. However, in the absence of NKCC1, BTD may impair insulin secretion via inhibition of NKCC2. This concept is supported by the fact that BTD severely worsened glucose tolerance in NKCC $1^{\mathrm{KO}}$ mice (Fig. $5 \mathrm{~B}$ and $\mathrm{C}$ ) and directly inhibited insulin secretion from their $\beta$-cells (Fig. 6F) expressing NKCC2 (Fig. 6G, H, I and J).

These results are in agreement with the concept that BTD impairs glucose homeostasis through a direct effect on insulin secretion (Furman 1981, Sandstrom 1988, 1990). However, the presence of NKCCs in $\beta$-cells with different pharmacological properties and their involvement in insulin secretion raise the possibility that low doses of BTD or isoform-specific inhibitors may be used to fine-tune insulin secretion in response to glucose.

\section{Declaration of interest}

The authors declare that there is no conflict of interest that could be perceived as prejudicing the impartiality of the research reported.

\section{Funding}

This work was supported by the American Diabetes Association.

\section{Acknowledgements}

The authors are most grateful to Dr Gary Shull (Department of Molecular Genetics, Biochemistry and Microbiology, University of Cincinnati) for providing heterozygous NKCC1 mice and to Dr Pierre Maechler (Université de Genève, Faculté de Médecine) for providing INS-1E $\beta$-cells.

\section{References}

Abramoff MD 2004 Image processing using ImageJ. Biophotonics International $1136-42$.
Adragna NC, Di Fulvio M \& Lauf PK 2004 Regulation of K-Cl cotransport: from function to genes. Journal of Membrane Biology 201 109-137. (doi:10. 1007/s00232-004-0695-6)

Akiyama K, Miyashita T, Mori T \& Mori N 2007 Expression of the $\mathrm{Na}^{+}{ }_{-}$ $\mathrm{K}^{+}-2 \mathrm{Cl}^{-}$cotransporter in the rat endolymphatic sac. Biochemical and Biophysical Research Communications 364 913-917. (doi:10.1016/j.bbrc. 2007.10.107)

Akiyama K, Miyashita T, Matsubara A \& Mori N 2010 The detailed localization pattern of $\mathrm{Na}^{+} / \mathrm{K}^{+} / 2 \mathrm{Cl}^{-}$cotransporter type 2 and its related ion transport system in the rat endolymphatic sac. Journal of Histochemistry and Cytochemistry 58 759-763. (doi:10.1369/jhc.2010.956045)

Alshahrani S \& Di Fulvio M 2012 Expression of the Slc12a1 gene in pancreatic $\beta$-cells: molecular characterization and in silico analysis. Cellular Physiology and Biochemistry 30 95-112. (doi:10.1159/000339050)

Ares GR, Caceres PS \& Ortiz PA 2011 Molecular regulation of NKCC2 in the thick ascending limb. American Journal of Physiology. Renal Physiology 301 F1143-F1159. (doi:10.1152/ajprenal.00396.2011)

Barg S, Galvanovskis J, Gopel SO, Rorsman P \& Eliasson L 2000 Tight coupling between electrical activity and exocytosis in mouse glucagonsecreting $\boldsymbol{\alpha}$-cells. Diabetes 49 1500-1510. (doi:10.2337/diabetes.49.9.1500)

Best L 2002 Evidence that glucose-induced electrical activity in rat pancreatic $\beta$-cells does not require KATP channel inhibition. Journal of Membrane Biology 185 193-200. (doi:10.1007/s00232-001-0114-1)

Best L 2005 Glucose-induced electrical activity in rat pancreatic $\beta$-cells: dependence on intracellular chloride concentration. Journal of Physiology 568 137-144. (doi:10.1113/jphysiol.2005.093740)

Best L, Yates AP \& Tomlinson S 1992 Stimulation of insulin secretion by glucose in the absence of diminished potassium $\left({ }^{86} \mathrm{Rb}^{+}\right)$permeability. Biochemical Pharmacology 43 2483-2485. (doi:10.1016/0006-2952(92) 90330-L)

Best L, Brown PD, Sener A \& Malaisse WJ 2010 Electrical activity in pancreatic islet cells: the VRAC hypothesis. Islets 2 59-64. (doi:10.4161/isl. 2.2.11171)

Bouwens L \& Rooman I 2005 Regulation of pancreatic $\beta$-cell mass. Physiological Reviews 85 1255-1270. (doi:10.1152/physrev.00025.2004)

Caumo A \& Luzi L 2004 First-phase insulin secretion: does it exist in real life? Considerations on shape and function American Journal of Physiology. Endocrinology and Metabolism 287 E371-E385. (doi:10.1152/ajpendo.00139. 2003)

Cuddapah VA \& Sontheimer H 2011 Ion channels and transporters (corrected) in cancer. 2. Ion channels and the control of cancer cell migration. American Journal of Physiology. Cell Physiology 301 C541-C549. (doi:10.1152/ajpcell.00102.2011)

Del Prato S, Marchetti P \& Bonadonna RC 2002 Phasic insulin release and metabolic regulation in type 2 diabetes. Diabetes 51 (Suppl 1) S109-S116. (doi:10.2337/diabetes.51.2007.S109)

Di Fulvio M \& Alvarez-Leefmans FJ 2009 The NKCC and NCC genes: an in silico view. In Physiology and Pathology of Chloride Transporters and Channels in the Nervous System: From Molecules to Diseases, 1st edn, pp 169-208. Eds FJ Alvarez-Leefmans \& E Delpire. Waltham, MA, USA: Academic Press, Incorporated.

Di Fulvio M, Frondorf K, Henkels KM, Lehman N \& Gomez-Cambronero J 2007 The Grb2/PLD2 interaction is essential for lipase activity, intracellular localization and signaling in response to EGF. Journal of Molecular Biology 367 814-824. (doi:10.1016/j.jmb.2007.01.021)

Drews G, Krippeit-Drews P \& Dufer M 2010 Electrophysiology of islet cells. Advances in Experimental Medicine and Biology 654 115-163. (doi:10.1007/ 978-90-481-3271-3_7)

Eberhardson M, Patterson S \& Grapengiesser E 2000 Microfluorometric analysis of $\mathrm{Cl}^{-}$permeability and its relation to oscillatory $\mathrm{Ca}^{2+}$ signalling in glucose-stimulated pancreatic $\beta$-cells. Cellular Signalling 12 781-786. (doi:10.1016/S0898-6568(00)00122-4)

Flagella M, Clarke LL, Miller ML, Erway LC, Giannella RA, Andringa A, Gawenis LR, Kramer J, Duffy JJ, Doetschman Tet al. 1999 Mice lacking the basolateral $\mathrm{Na}-\mathrm{K}-2 \mathrm{Cl}$ cotransporter have impaired epithelial chloride secretion and are profoundly deaf. Journal of Biological Chemistry 274 26946-26955. (doi:10.1074/jbc.274.38.26946) 
Furman BL 1981 Impairment of glucose tolerance produced by diuretics and other drugs. Pharmacology \& Therapentics 12 613-649. (doi:10.1016/01637258(81)90102-9)

Gamba G 2005 Molecular physiology and pathophysiology of electroneutral cation-chloride cotransporters. Physiological Reviews 85 423-493.

(doi:10.1152/physrev.00011.2004)

Gavrikov KE, Nilson JE, Dmitriev AV, Zucker CL \& Mangel SC 2006 Dendritic compartmentalization of chloride cotransporters underlies directional responses of starburst amacrine cells in retina. PNAS $\mathbf{1 0 3}$ 18793-18798. (doi:10.1073/pnas.0604551103)

Gimenez I \& Forbush B 2007 The residues determining differences in ion affinities among the alternative splice variants $\mathrm{F}, \mathrm{A}$, and $\mathrm{B}$ of the mammalian renal Na-K-Cl cotransporter (NKCC2). Journal of Biological Chemistry 282 6540-6547. (doi:10.1074/jbc.M610780200)

Guillausseau PJ, Meas T, Virally M, Laloi-Michelin M, Medeau V \& Kevorkian JP 2008 Abnormalities in insulin secretion in type 2 diabetes mellitus. Diabetes \& Metabolism 34 (Suppl 2) S43-S48. (doi:10.1016/S12623636(08)73394-9)

Herbach N, Bergmayr M, Goke B, Wolf E \& Wanke R 2011 Postnatal development of numbers and mean sizes of pancreatic islets and $\beta$-cells in healthy mice and GIPR $(\mathrm{dn})$ transgenic diabetic mice. PLoS ONE 6 e22814. (doi:10.1371/journal.pone.0022814)

Hoffmann EK, Lambert IH \& Pedersen SF 2009 Physiology of cell volume regulation in vertebrates. Physiological Reviews 89 193-277. (doi:10.1152/ physrev.00037.2007)

Hou JC, Min L \& Pessin JE 2009 Insulin granule biogenesis, trafficking and exocytosis. Vitamins and Hormones 80 473-506. (doi:10.1016/j.bbr.2011. 03.031)

Isenring P, Jacoby SC, Payne JA \& Forbush B III 1998 Comparison of $\mathrm{Na}-\mathrm{K}-\mathrm{Cl}$ cotransporters, NKCC1, NKCC2, and the HEK cell Na-K-Cl cotransporter. Journal of Biological Chemistry 273 11295-11301. (doi:10. 1074/jbc.273.18.11295)

Iwamoto LM, Fujiwara N, Nakamura KT \& Wada RK 2004 Na-K-2Cl cotransporter inhibition impairs human lung cellular proliferation. American Journal of Physiology. Lung Cellular and Molecular Physiology 287 L510-L514. (doi:10.1152/ajplung.00021.2004)

Kaku K, Fiedorek FT Jr, Province M \& Permutt MA 1988 Genetic analysis of glucose tolerance in inbred mouse strains. Evidence for polygenic control. Diabetes 37 707-713. (doi:10.2337/diabetes.37.6.707)

Kashyap SR \& Defronzo RA 2007 The insulin resistance syndrome: physiological considerations. Diabetes \& Vascular Disease Research 4 13-19. (doi:10.3132/dvdr.2007.001)

Kinard TA \& Satin LS 1995 An ATP-sensitive $\mathrm{Cl}^{-}$channel current that is activated by cell swelling, cAMP, and glyburide in insulin-secreting cells. Diabetes 44 1461-1466. (doi:10.2337/diabetes.44.12.1461)

Lang F, Lepple-Wienhues A, Szabo I, Siemen D \& Gulbins E 1998 Cell volume in cell proliferation and apoptotic cell death. Contributions to Nephrology 123 158-168.

Li DS, Yuan YH, Tu HJ, Liang QL \& Dai LJ 2009 A protocol for islet isolation from mouse pancreas. Nature Protocols 4 1649-1652. (doi:10.1038/nprot. 2009.150)

Lindstrom P, Norlund L \& Sehlin J 1986 Potassium and chloride fluxes are involved in volume regulation in mouse pancreatic islet cells. Acta Physiologica Scandinavica 128 541-546. (doi:10.1111/j.1748-1716.1986. tb08010.x)

Lindstrom P, Norlund L, Sandstom PE \& Sehlin J 1988 Evidence for co-transport of sodium, potassium and chloride in mouse pancreatic islets. Journal of Physiology 400 223-236.

Majid A, Speake T, Best L \& Brown PD 2001 Expression of the $\mathrm{Na}^{+} \mathrm{K}^{+}-$ $2 \mathrm{Cl}^{-}$cotransporter in $\alpha$ and $\beta$ cells isolated from the rat pancreas. Pflügers Archiv: European Journal of Physiology 442 570-576. (doi:10.1007/ s004240100566)

McGuinness OP, Ayala JE, Laughlin MR \& Wasserman DH 2009 NIH experiment in centralized mouse phenotyping: the Vanderbilt experience and recommendations for evaluating glucose homeostasis in the mouse. American Journal of Physiology. Endocrinology and Metabolism 297 E849-E855. (doi:10.1152/ajpendo.90996.2008)
Merglen A, Theander S, Rubi B, Chaffard G, Wollheim CB \& Maechler P 2004 Glucose sensitivity and metabolism-secretion coupling studied during two-year continuous culture in INS-1E insulinoma cells. Endocrinology 145 667-678. (doi:10.1210/en.2003-1099)

Montanya E, Nacher V, Biarnes M \& Soler J 2000 Linear correlation between $\beta$-cell mass and body weight throughout the lifespan in Lewis rats: role of $\beta$-cell hyperplasia and hypertrophy. Diabetes 49 1341-1346. (doi:10.2337/ diabetes.49.8.1341)

Nickell WT, Kleene NK \& Kleene SJ 2007 Mechanisms of neuronal chloride accumulation in intact mouse olfactory epithelium. Journal of Physiology $\mathbf{5 8 3}$ 1005-1020. (doi:10.1113/jphysiol.2007.129601)

Nishimura M, Kakigi A, Takeda T, Takeda S \& Doi K 2009 Expression of aquaporins, vasopressin type 2 receptor, and $\mathrm{Na}^{+} \mathrm{K}^{+} \mathrm{Cl}^{-}$cotransporters in the rat endolymphatic sac. Acta Oto-laryngologica 129 812-818. (doi:10.1080/00016480802441754)

O’Brien TG, Prettyman R, George KS \& Herschman HR 1988 A phorbol ester-nonproliferative variant of Swiss $3 \mathrm{~T} 3$ cells is deficient in $\mathrm{Na}^{+} \mathrm{K}^{+} \mathrm{Cl}^{-}$ cotransport activity. Journal of Cellular Physiology 134 302-306. (doi:10.1002/jcp.1041340219)

Ohsawa R, Miyazaki H, Niisato N, Shiozaki A, Iwasaki Y, Otsuji E \& Marunaka Y 2010 Intracellular chloride regulates cell proliferation through the activation of stress-activated protein kinases in MKN28 human gastric cancer cells. Journal of Cellular Physiology 223 764-770.

Panet R, Markus M \& Atlan H 1994 Bumetanide and furosemide inhibited vascular endothelial cell proliferation. Journal of Cellular Physiology 158 121-127. (doi:10.1002/jcp.1041580115)

Panet R, Marcus M \& Atlan H 2000 Overexpression of the $\mathrm{Na}(+) /$ $\mathrm{K}(+) / \mathrm{Cl}(-)$ cotransporter gene induces cell proliferation and phenotypic transformation in mouse fibroblasts. Journal of Cellular Physiology 182 109-118. (doi:10.1002/(SICI)1097-4652(200001)182:1 < 109::AIDJCP12>3.0.CO;2-A)

Panet R, Eliash M, Pick M \& Atlan H $2002 \mathrm{Na}(+) / \mathrm{K}(+) / \mathrm{Cl}(-)$ cotransporter activates mitogen-activated protein kinase in fibroblasts and lymphocytes. Journal of Cellular Physiology 190 227-237. (doi:10.1002/jcp. 10055)

Sandstrom PE 1988 Evidence for diabetogenic action of bumetanide in mice. European Journal of Pharmacology 150 35-41. (doi:10.1016/0014-2999(88) 90747-9)

Sandstrom PE 1990 Bumetanide reduces insulin release by a direct effect on the pancreatic $\beta$-cells. European Journal of Pharmacology 187 377-383. (doi:10.1016/0014-2999(90)90365-D)

Seghers V, Nakazaki M, DeMayo F, Aguilar-Bryan L \& Bryan J 2000 Sur1 knockout mice. A model for K(ATP) channel-independent regulation of insulin secretion. Journal of Biological Chemistry 275 9270-9277. (doi:10. $1074 / \mathrm{jbc} .275 .13 .9270)$

Sehlin J 1978 Interrelationship between chloride fluxes in pancreatic islets and insulin release. American Journal of Physiology 235 E501-E508.

Shiozaki A, Miyazaki H, Niisato N, Nakahari T, Iwasaki Y, Itoi H, Ueda Y, Yamagishi H \& Marunaka Y 2006 Furosemide, a blocker of $\mathrm{Na}^{+} / \mathrm{K}^{+} / 2 \mathrm{Cl}^{-}$cotransporter, diminishes proliferation of poorly differentiated human gastric cancer cells by affecting G0/G1 state. Journal of Physiological Sciences 56 401-406. (doi:10.2170/physiolsci.RP010806)

Simon DB, Karet FE, Hamdan JM, DiPietro A, Sanjad SA \& Lifton RP 1996 Bartter's syndrome, hypokalaemic alkalosis with hypercalciuria, is caused by mutations in the $\mathrm{Na}-\mathrm{K}-2 \mathrm{Cl}$ cotransporter NKCC2. Nature Genetics $\mathbf{1 3}$ 183-188. (doi:10.1038/ng0696-183)

Somers G, Sener A, Devis G \& Malaisse WJ 1980 The stimulus-secretion coupling of glucose-induced insulin release. XLV. The anion-osmotic hypothesis for exocytosis. Pflügers Archiv: European Journal of Physiology $\mathbf{3 8 8}$ 249-253. (doi:10.1007/BF00658490)

Tamagawa T \& Henquin JC 1983 Chloride modulation of insulin release, ${ }^{86} \mathrm{Rb}^{+}$efflux, and ${ }^{45} \mathrm{Ca}^{2+}$ fluxes in rat islets stimulated by various secretagogues. Diabetes 32 416-423. (doi:10.2337/diabetes.32.5.416)

Tchoukalova YD, Harteneck DA, Karwoski RA, Tarara J \& Jensen MD 2003 A quick, reliable, and automated method for fat cell sizing. Journal of Lipid Research 44 1795-1801. (doi:10.1194/jlr.D300001-JLR200) 
Toye AA, Lippiat JD, Proks P, Shimomura K, Bentley L, Hugill A, Mijat V, Goldsworthy M, Moir L, Haynes A et al. 2005 A genetic and physiological study of impaired glucose homeostasis control in C57BL/6J mice.

Diabetologia 48 675-686. (doi:10.1007/s00125-005-1680-z)

Wall SM, Knepper MA, Hassell KA, Fischer MP, Shodeinde A, Shin W, Pham TD, Meyer JW, Lorenz JN, Beierwaltes WH et al. 2006 Hypotension in NKCC1 null mice: role of the kidneys. American Journal of Physiology. Renal Physiology 290 F409-F416. (doi:10.1152/ajprenal.00309.2005)

Wang Z \& Thurmond DC 2009 Mechanisms of biphasic insulin-granule exocytosis - roles of the cytoskeleton, small GTPases and SNARE proteins. Journal of Cell Science 122 893-903. (doi:10.1242/jcs.034355)

Wang C, Shimizu-Okabe C, Watanabe K, Okabe A, Matsuzaki H, Ogawa T, Mori N, Fukuda A \& Sato K 2002 Developmental changes in KCC1, KCC2, and NKCC1 mRNA expressions in the rat brain. Brain Research. Developmental Brain Research 139 59-66. (doi:10.1016/S0165-3806(02) 00536-9)
Xue H, Liu S, Ji T, Ren W, Zhang XH, Zheng LF, Wood JD \& Zhu JX 2009 Expression of NKCC2 in the rat gastrointestinal tract. Neurogastroenterology and Motility 21 1068-1089. (doi:10.1111/j.13652982.2009.01334.x)

Zhu JX, Xue H, Ji T \& Xing Y 2011 Cellular localization of NKCC2 and its possible role in the $\mathrm{Cl}(-)$ absorption in the rat and human distal colonic epithelia. Translational Research 158 146-154. (doi:10.1016/j.trsl. 2011.04.003)

Received 27 July 2012

Accepted 3 August 2012

Made available online as an Accepted Preprint 7 August 2012 